Bangladesh J. Bot. 40(1): 9-15, 2011 (June)

\title{
MORPHOLOGICAL AND ANATOMICAL INVESTIGATIONS ON THREE ALLIUM L. (LILIACEAE) SPECIES OF EAST ANATOLIA, TURKEY
}

\author{
Canan Özdemir, Kâmuran AKtaş and Yasin Altan \\ Department of Biology, Faculty of Science and Art, Celal Bayar University, Manisa-Turkey
}

Key words: Allium, Anatomy, Morphology

\begin{abstract}
Three East Anatolia species of Allium namely, A. karsianum Fomin, A. kunthianum Vved., A. rupestre Steven are compared morphologically and anatomically. The results showed that all the species investigated can be distinguished by their morphological and anatomical characters.

\section{Introduction}

The genus Allium L. consists of more than 600 species distributed across the northern hemisphere (Van Raamsdonk and De Vries 1992). The first knowledge about Allium species of Turkey was given by Boissier (1884). In Turkey, there are 146 species of Allium (Seçmen et al. 1998 ) and $35 \%$ of these species are endemic (Özhatay 1986). These species have been described in Flora of Turkey and East Aegean Islands (Kollmann 1984, Davis 1988). The three species (A. karsianum Fomin, A. kunthianum Vved., A. rupestre Steven) occur naturally in East Anatolia, have economic importance (Davis 1988) and thus, the present investigation was undertaken.

\section{Materials and Methods}

Allium karsianum Fomin, A.kunthianum Vved. and A. rupestre Steven were collected from natural populations of East Anatolia, Turkey. Some of these specimens were used for morphological and anatomical studies, while some were deposited in the herbarium of Celal Bayar University Turkey. Samples were fixed in $70 \%$ alcohol for anatomical studies. In addition some of the materials were preserved in glycerol and 70\% alcohol (1:1), and were used for preparing a cross section of root, scape and leaves. The sections were stained with Sartur solution and camera lucida drawings of the sections were made. Details of the collected specimens are given in Table 1.

Table 1. Locality, collector and collection no. of three Allium species.

\begin{tabular}{llc}
\hline Species & Locality and collector & Collection number \\
\hline A. karsianum & A8 Erzurum, Senkaya, Gülveren Village, Open Field, 14.08.1997, & 6722 \\
& Yasin Altan & \\
A. kunthianum & A9 Artvin, Savsat, Sahara Mountain, Alpine meadow, 2500m, & 6681 \\
& 23.08.1996, Yasin Altan & \\
A. rupestre & A8 Erzurum, Oltu, Camlıbel Village, Steppe, 1400m, 01.08.1996, & 6646 \\
& Yasin Altan & \\
\hline
\end{tabular}
\end{abstract}

\section{Results and Discussion}

Morphological properties: A. karsianum Fomin: Bulbs, ovoid-globose, 1-2 cm in diameter and $1-2 \mathrm{~cm}$ long with outer tunics papyraceous, grayish-white. Stems $18-35 \mathrm{~cm}$ high, erect, covered by leaf sheaths up to $1 / 3-2 / 3$ of its length. Leaves $2-4$, narrowly linear, $2.0-2.5 \mathrm{~mm}$ breadth upper leaf longer than inflorescence. Inflorescence many flowered. Pedicels unequal, $2-5 \mathrm{~mm} \times$ as long as perianth. Perianth narrowly cylindrical, pale pink to white with a purple midvein, $4-5 \mathrm{~mm}$ 
long and 1.5-2.0 mm wide. Stamens 6 and included. Capsules 4-6 mm long and 2.5-4.0 mm wide (Figs 1a, 2).
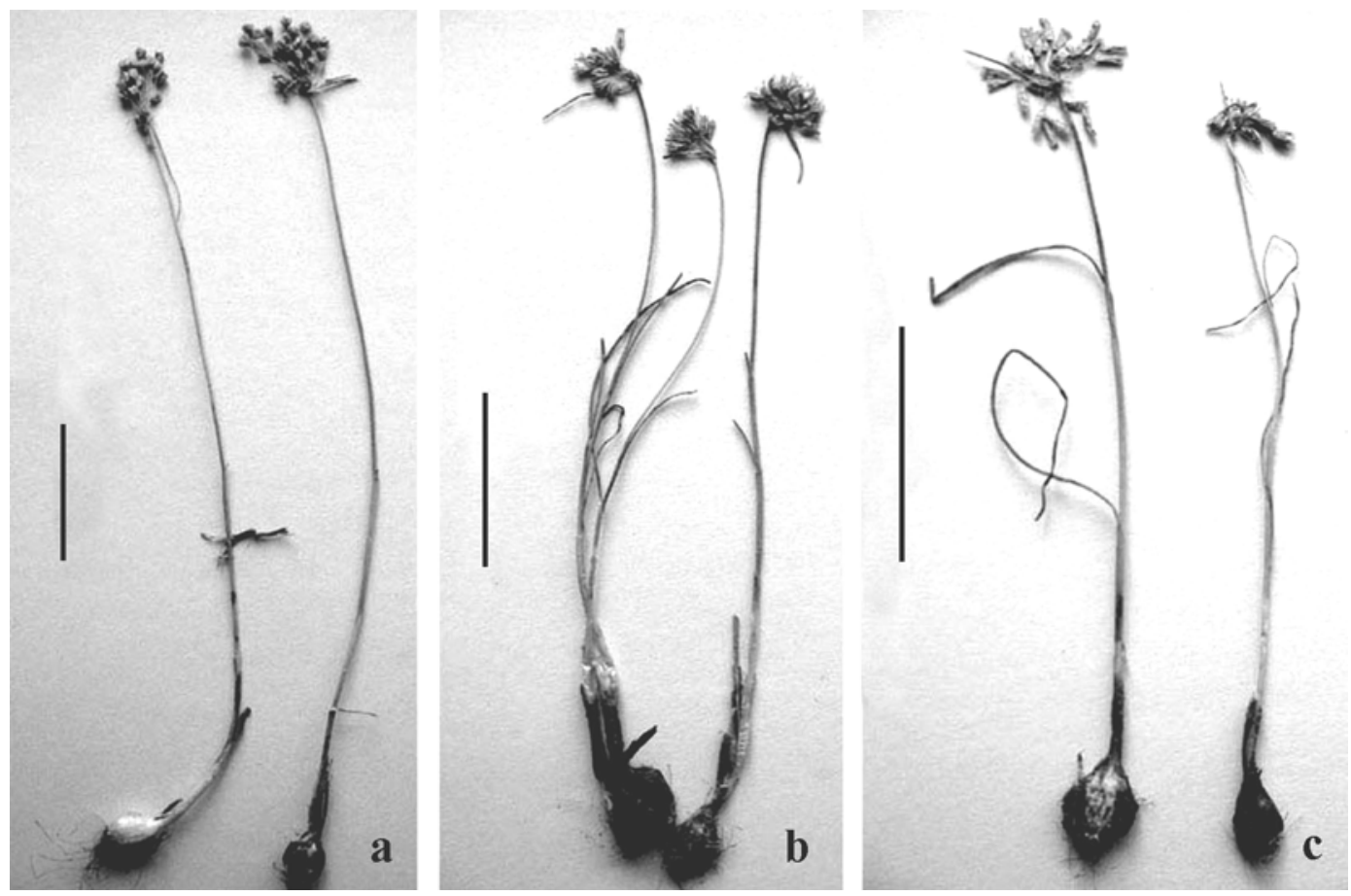

Fig. 1. General apperance of Allium species; a. A. karsianum, b. A. kunthianum, c. A. rupestre. Bar $=5 \mathrm{~cm}$.

A kunthianum Vved: Bulbs, ovoid, $0.5-1.5 \mathrm{~cm}$ long, $0.8-1.3 \mathrm{~cm}$ diameter, with outer tunics brownish, papyraceous. Stems $8-25 \mathrm{~cm}$ high, covered by leaf sheaths for $1 / 3-2 / 3$ of its length. Leaves $2-4$, semicylindrical, $1 \mathrm{~mm}$ breadth. Spathes longer than inflorescence. İnflorescence is few flowered, fastigiate-hemispherical. Pedicels are subequal, usually shorter than perianth. Perianth narrowlly campanulate, deep rose with a deep purple midvein, linear-oblong, $5-8 \mathrm{~mm}$ long and $0.8-1.5 \mathrm{~mm}$ wide. Stamens 6 and included. Capsules $1.5-2.5 \mathrm{~mm}$ long and $1-2 \mathrm{~mm}$ width (Figs 1b, 2).

A. rupestre Steven: Bulbs ovoid, $1.0-1.5 \mathrm{~cm}$ long, $8-20 \mathrm{~mm}$ in diameter. The outer bulb tunics yellow-white, membranous. Stem $17-35 \mathrm{~cm}$ high, erect, covered by leaf sheaths for $1 / 3-2 / 3$ of its length. Leaves $2-3$, filiform, $0.4-1.0 \mathrm{~mm}$ broad, sheathing lower half of the stem. Spathe longer than inflorescence or subequal with unequal valves. Valves of spathe linear at base, narrowed above into a long, slender appendage, many times longer than umbel. Inflorescence 5 20 flowered. Pedicels 5 - $15 \mathrm{~mm}$ long. Perianth segments pale, pink-pinkish white to pinkish, brownish-purple at margin, midvein purple, 4-6 mm long and $1.0-2.5 \mathrm{~mm}$ wide. Stamens 6 and included. Capsules $3-4 \mathrm{~mm}$ long and $1.5-2.0 \mathrm{~mm}$ wide (Figs 1c, 2). 

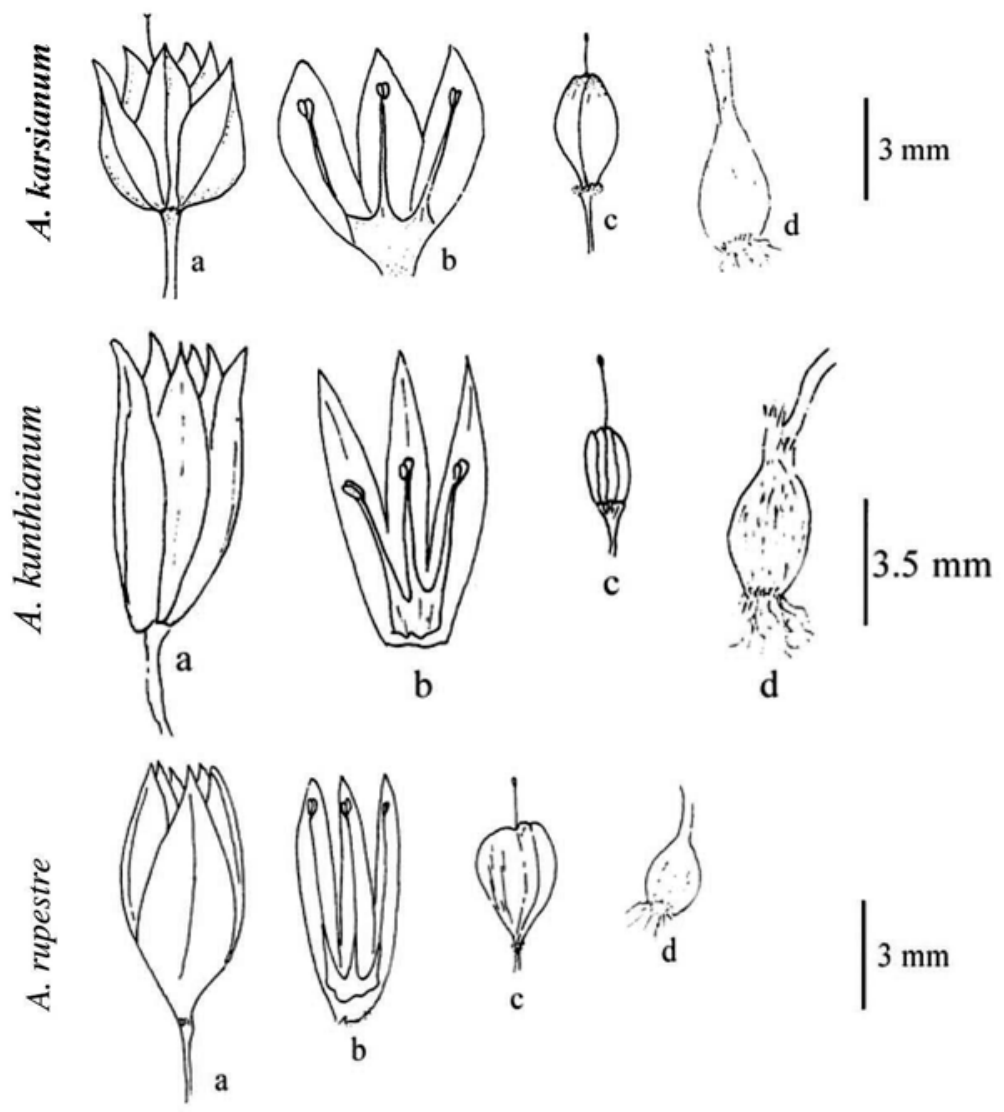

Fig. 2. Parts of Allium species; a. Flower, b. L.S. of perianth with stamens, c. Ovary and style, d. Bulb.

\section{Anatomical properties}

\section{A. karsianum Fomin}

Root: Epidermis single layered, cortex 4 - 6 layered consisting of ovoidal cells. The wall thickening of the endodermis three-sided. Pericycle cells very small and distinguishable. Phloem region is very small. Single metaxylem is present on the median part of vascular cylinder. 3 - 4 xylem strands are present on the periphery of the vascular cylinder and these strands reach the pericycle (Fig. 3a).

Scape: Epidermis is single layered, consists of prismatical thick-walled cells with thick cuticle. Parenchymatic cortex cells are orbicular, 7 - 12 layered. Outer cortical cells are small and with thickened wall. Vascular bundles are arranged in two rings. Vascular bundles which are located in the centre of the scape are big and 4 in number. There are very wide pith spaces in the centre of scape (Fig. 4i a, b).

Leaf: Epidermis is composed of cubical cells and covered by well developed cuticle. Palisade tissue 1 - 2 layered, many vascular bundle in the mesophyl tissue. Spongy parenchyma tissue compact, with bigger cells in the centre (Fig. $5 \mathrm{i} \mathrm{a}, \mathrm{b}$ ). 


\section{A. kunthianum Vved.}

Root: Epidermis two layered, cells prismatical and thin-walled. Cortex 4-5 layered, cortex cells bigger the inner ones. The wall thickenings of endodermis cells three-sided. Pericyle cells under endodermis, 1-2 metaxylem; and present in the centre vascular cylinder. Xylem strands 3-4 in number and reach the pericyle (Fig. 3b).
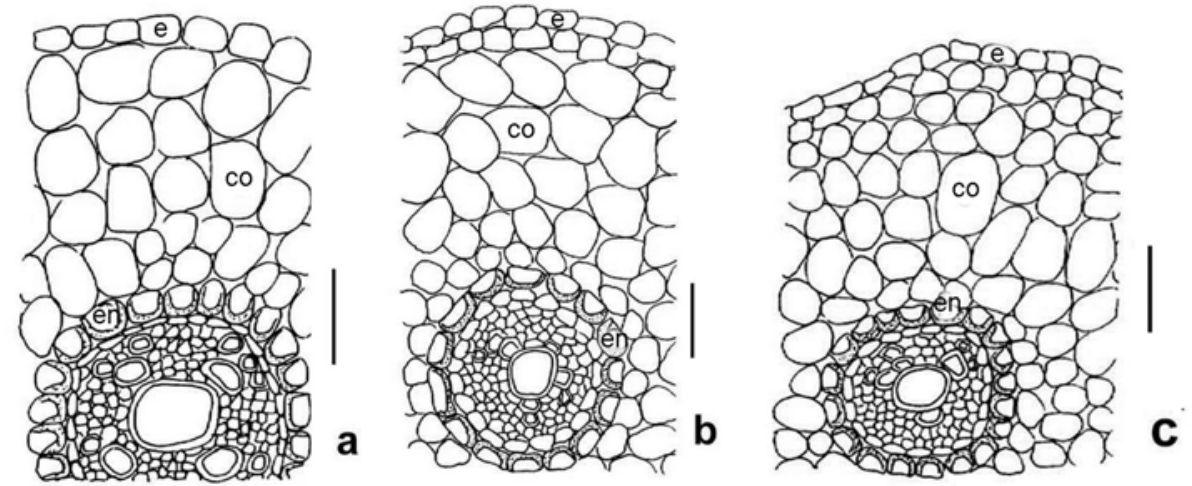

Fig. 3. Cross-section of roots of Allium karsianum (a), A. kunthianum (b) and A. rupestre (c). e. epidermis, co. cortex, en. endodermis. Bars $=\mathrm{a}, 40 \mu \mathrm{m} ; \mathrm{b}, 20 \mu \mathrm{m} ; \mathrm{c}, 30 \mu \mathrm{m}$.

Scape: Epidermis tissue single layered, cells walls slightly thickened with thick cuticle. Cortex cells 7-9 layered and orbicular smaller on the outer part of cortex. The cells have thickened wall, some cells of cortex with big diameter have starch grain. Vascular bundles are arranged is two rings. This bundles have the same as in size. The bundles in inner part or cortex are 4 in number (Fig. 4ii a, b).

Leaf: Epidermal cells cubical, palisade tissue one layered. Many vascular bundles in the mesophyl tissue (Fig. 5ii a, b).
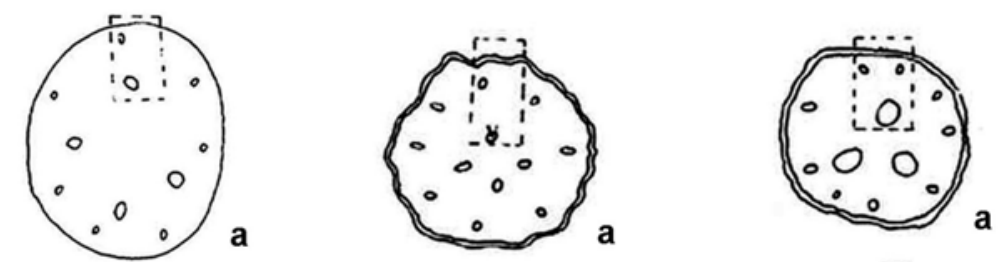

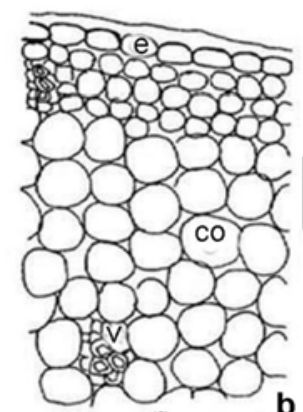

(i)

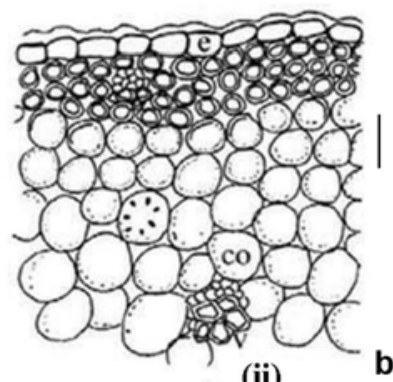

(ii)

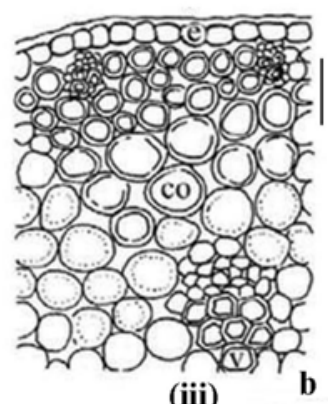

(iii)

Fig. 4. Cross-sections of scapes of Allium karsianum (i), A. kunthianum (ii), A. rupestre (iii). a. Cross-section of a scape showing gross morphology, b. A part enlarged (e. epidermis, co. cortex, v. vascular bundle). Bars $=70 \mu \mathrm{m}$. 


\section{A. rupestre Steven}

Root: Single layered epidermis, cells thin walled and prismatical in shape. Cortex 5-6 layered, cells are ovoidal and have intercellular spaces. The wall thickenings of endodermis single layered are clear in cross-section of root. This thickenings are three-sided. A single metaxylem in the center and 3-4 xylem strands on the periphery of metaxylem, some of xylem strands do not reach the pericycle (Fig. 3c).

Scape: Single layered epidermis with thick cuticle. Wall of epidermis cells are slihgtly thickened . Cortex consists of orbicular cells, outer ones are smaller than the cells located at the inner scape. Some of the cortex cells are thick-walled. Vascular bundles are arranged in two ring, the outer ring are smaller than inner ring, Large vascular bundles are 3-5 in number. There is pith centre of scape (Fig. 4iii a, b).

Leaf: Cross sections of semicylindrical with many ribs. Epidermis is covered by a well developed cuticle. Palisade tissue is 2-3 layered. The leaf is fistulous in the centre and spongy tissue is limited to a narrow peripheral belt. There are many vascular bundlles (Fig. 5iii a, b).
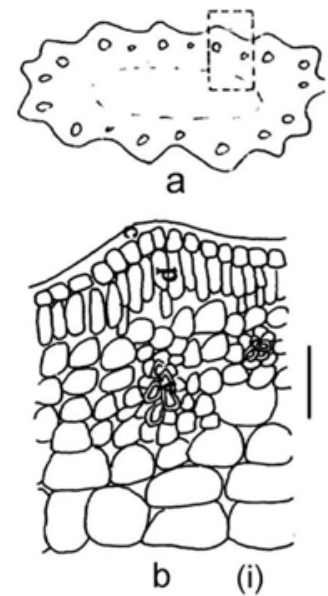
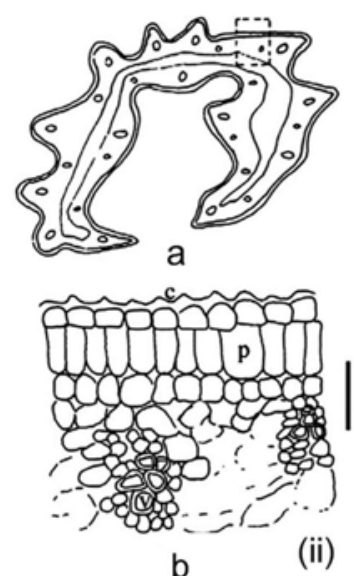

(ii)

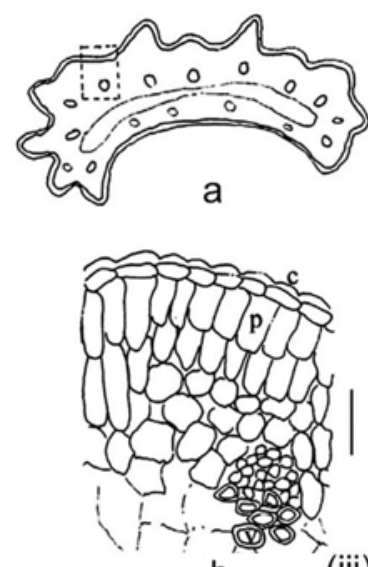

b

(iii)

Fig. 5. Cross-section of leaves of Allium karsianum (i) , A. kunthianum (ii), A. rupestre (iii). a. Cross-section of leaves, b. A part of enlarged. c, cuticle; $p$, palisade parenchyma; $v$, vascular bundle.

Dimentions of anatomical structures of the three species are within the range of each other (Table 2).

Table 2. Dimentions (in $\mu \mathrm{m}$ ) anatomical structures of three Allium species

\begin{tabular}{|c|c|c|c|c|c|c|c|}
\hline & \multicolumn{2}{|c|}{ A. karsianum } & \multicolumn{2}{|c|}{ A. kunthianum } & \multicolumn{2}{|c|}{ A. rupestre } \\
\hline & & Breadth & Length & Breadth & Length & Breadth & Length \\
\hline \multirow[t]{5}{*}{ Root } & Epidermis & $7-19$ & $5-12$ & $10-26$ & $7-20$ & $9-28$ & $7-19$ \\
\hline & Endodermis & $8-14$ & $7-10$ & $7-10$ & $2-5$ & $9-21$ & $4-11$ \\
\hline & Pericycle & $5-7$ & $2-5$ & $7-10$ & $5-7$ & $4-9$ & $2-7$ \\
\hline & Diameter of cortex & $17-45$ & & $10-36$ & & $11-42$ & \\
\hline & Diameter of metaxylem & $24-40$ & & $14-19$ & & $17-29$ & \\
\hline \multirow[t]{3}{*}{ Scape } & Thickening of cuticle & $5-7$ & & $2-5$ & & $5-10$ & \\
\hline & Epidermis & $7-14$ & $11-12$ & $12-21$ & $7-11$ & $12-14$ & $5-10$ \\
\hline & Diameter of cortex & $7-83$ & & $7-71$ & & $10-33$ & \\
\hline \multirow[t]{2}{*}{ Leaf } & Thickening of cuticle & $5-12$ & & 1- 4 & & $5-10$ & \\
\hline & Epidermis & $7-12$ & $6-17$ & $10-17$ & & $7-19$ & $5-7$ \\
\hline
\end{tabular}


The three Allium species investigated have usually ovoid, ovoid-oblong bulbs, one or both spathe valves longer than umbel. These features are characteristics for Codonoprasum section of Allium. The stamens of A. rupestre have slightly exserted from the perigon. This feature distinguishes them from the other two species. The feature has been observed on the stamens of Allium karacae M. Koyuncu which belong to section Scorodon (Ünal and Duman 2002) and Allium altyncolicum Friesen which belong to Schoenoprasum (Friesen 1996).

Anatomical structures of roots of the three species are typical monocotyledonous. Three-sided thickenings are very clear on the walls of the endodermal cells of roots of all the species. The same features have been observed in roots of some species belonging to Liliaceae and Irıdaceae, while a thickening to pericyle has been observed on some other species of Liliaceae and Iridaceae (Özyurt 1978). Two of the investigated species have single metaxylem in the centre of roots, but A. kunthianum has 1 - 2 metaxylem.

The number of protoxylem groups are 3-4 in number, the feature observed in the roots of Merendera trigyna (Adam) Stapf and M. attica (Spruner.) Boiss \& Spruner (Liliaceae) and Crocus pulchellus Herbert, C. fleischeri Gay and C. danforiae Maw (Iridaceae) (Özyurt 1978, Özdemir et al. 2004). Vascular bundles are arranged in two rings on the scape of investigated species. The same features has been observed in Crocus aerius Herb and C. pulchellus (Özyurt 1978, Özdemir and Akyol 2004). Kutbay et al. (2001) and Özdemir (2003) have emphasized that there were more than two rings consisting of vascular bundles on the scape of Romulea columnae Seb.\& Mauri subsp. columnae and Lilium ciliatum P.H. Davis (Kutbay et al. 2001, Özdemir 2003).

The leaf epidermis of investigated species has a well developed cuticle with prominent ridges at vascular bundles. Spongy parenchyma tissue is limited to a peripheral belt except in $A$. karisanum, where the tissue is rather compact with bigger cells in the central part. The same feature has been observed in leaf cross-section of Allium pilosum Sibth. \& Sm. belonging to Codonoprasum section (Brullo et al. 2001).

\section{References}

Boissier E 1884. Flora Orientalis. V. 222-284, Geneve et Basileae.

Brullo S A Guglielmo P Pavone and C Salmeri 2001. Cytotaxonomical notes on some rare endemic species of Allium (Alliaceae) from Greece. Caryologia 54(1): 37-57.

Davis PH 1988. Flora of Turkey and East Aegean Islands. Vol. 10, Edinburgh Univ. Press, Edinburgh.

Fahn A 1982. Plant Anatomy. Pergamon Press, Oxford.

Friesen N 1996. A taxonomic and chorological revision of the genus Allium L. sec. Schoenoprosum Dumort. Candollea 51(2): 461-473.

Kollmann F 1984. Allium L. In: Flora of Turkey and East Aegean Islands, Davis P.H. (Ed.). Vol. 8. Edinburgh Univ. Press, Edinburgh.

Kutbay HG, C Özdemir and M Keskin. 2001. An anatomical study on Romulea columnae Seb. \& Mauri subsp. columnae (Irıdaceae). J. Econ. Taxan. Bot. Additional Series 19: 79-85.

Özdemir C 2003. The morphological, anatomical and cytological properties of endemic Lilium ciliatum P.H. Davis (Liliaceae) in Turkey. Pak. J. Bot. 35 (1): 99-110.

Özdemir C and Y Akyol. 2004. The morphological and anatomical studies on Crocus pulchellus Herbert (Irıdaceae) in Turkey. J. Econ. Taxon. Bot. 28(2): 237-245.

Özdemir C, Y Akyol and E Alçıtepe 2004. The morphological and anatomical studies on endemic two Crocus species of Turkey Area. Pak. J. Bot. 36(1): 103-113.

Özhatay N 1986. Kuzey Anadolu'da yetişen Allium L. türleri ve bunların kromozom sayıları. Doğa T. Bio. D. 10(3): 452-458. 
Özyurt S 1978. Palandöken Dağları çevresinin Liliaceae ve Iridaceae familyasına ait bazı geofitleri üzerinde morfolojik ve ekolojik incelemeler. Atatürk Üniv. Basım evi.

Seçmen Ö, Y Gemici, L Bekat and E Leblebici 1998. Tohumlu Bitkiler Sistematiği. E.Ü. Fen Fak. Kitaplar serisi No: 116, 5. bask1, İzmir.

Ünal F and H Duman 2002. Cytotaxonomic studies on four Allium L. (Liliaceae) species endemic to Turkey. Caryologia 55(2): 175-180.

Van Raamsdonk LWD and T De Vries 1992. Biosystematic studies in Allium L. Section Cepa. Bot. J. Linn. Soc. 109: 131-143.

(Manuscript received on 17 February, 2007; revised on 31 May, 2011) 